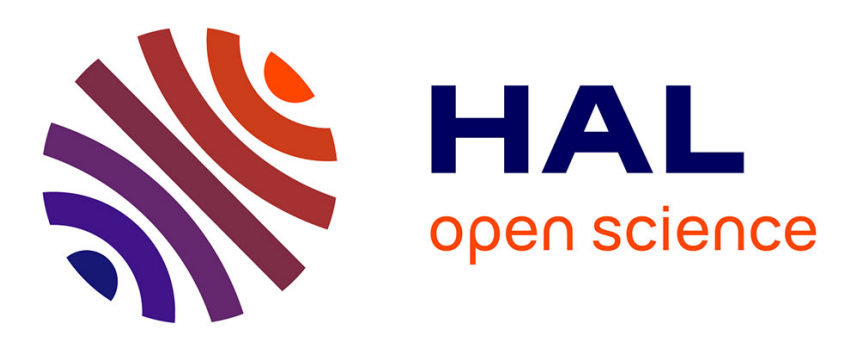

\title{
A relational perspective on the dynamics of the organic sector in Austria, Italy, and France
}

Ika Darnhofer, Simona d'Amico, Eve Fouilleux

\section{To cite this version:}

Ika Darnhofer, Simona d'Amico, Eve Fouilleux. A relational perspective on the dynamics of the organic sector in Austria, Italy, and France. Journal of Rural Studies, 2018, 68, pp.200-212. 10.1016/j.jrurstud.2018.12.002 . hal-01971731

\section{HAL Id: hal-01971731 \\ https://hal.science/hal-01971731}

Submitted on 29 Jun 2020

HAL is a multi-disciplinary open access archive for the deposit and dissemination of scientific research documents, whether they are published or not. The documents may come from teaching and research institutions in France or abroad, or from public or private research centers.
L'archive ouverte pluridisciplinaire HAL, est destinée au dépôt et à la diffusion de documents scientifiques de niveau recherche, publiés ou non, émanant des établissements d'enseignement et de recherche français ou étrangers, des laboratoires publics ou privés. 


\title{
A relational perspective on the dynamics of the organic sector in Austria, Italy, and France
}

\author{
Ika Darnhofer, Simona D’Amico, Eve Fouilleux
}

\begin{abstract}
Despite a common legal framework at EU-level, organic farming has developed differently in Member States. Previous analyses showed the influence of various factors on the development of the organic sector, including public policies, discourses, and marketing channels. Building on a relational perspective, we propose a conceptual framework that provides a situated understanding of national trajectories. We argue that the organic sector emerges based on relations between organic actors, policymakers, mainstream farmers associations, advocacy groups, and actors along the food chain. Based on these relations, we analyse the development of the organic sector in Austria, Italy, and France. We show that its dynamics result from a complex and evolving intertwining of relations over time. These dynamics are unpredictable, as they depend on whether and how actors can build and maintain relations between organic agriculture and broader issues in the agrifood system, such as the maintenance of family farms, environmental protection, gastronomic heritage, fairness in the food chain, or export promotion. The relational perspective highlights the historicity of relations, as well as the extent to which relations are influenced by the temporal and the spatial context. By framing the agrifood system as an ensemble of emergent social practices rather than a field of invariant logic and automatic unfoldings, the relational perspective emphasises the importance of seizing windows of opportunity, and the role of creativity in actions.
\end{abstract}

Key words. Organic farming, Organic trajectory, Agrifood system, Western Europe, Relational sociology

\section{Introduction}

Organic farming in Europe is a much debated issue. While it may seem to be a niche - with only $6.2 \%$ of the total Utilized Agricultural Area in the EU-28 (EC, 2016) - it is rather prominent in the public discourse. Organic farming is summoned by some to address individual issues such as food that is free of pesticideresidues, promoting animal welfare, reducing nitrate in surface and ground water, preserving biodiversity, or protecting the climate (Bellon and Penvern, 2014). For others, it is a comprehensive alternative to the modernisation of agriculture, striving for fairness in producer-consumer relationships, and enabling farmer autonomy (Lockeretz, 2007; Freyer and Bingen, 2014; Poméon et al., 2017). Of all the 'alternatives' to modernisation in agriculture, it is the only one that has a dedicated regulation at EU-level, where Action Plans were drafted by the European Commission and by Member States, and where customized measures to support its development are included in the agri-environmental programmes of many Member States. The sector continues to be dynamic, with the area under organic agriculture growing at a rate of $6 \%$ per year between 2002 and 2015 in the EU-28 (EC, 2016), and the market for organic food growing by 7\% per year (IFOAM EU, 2016).

Yet, despite a common regulation since 1991, it is striking that the development of agricultural land that is certified organic varies widely among countries. This may be exemplified by the three countries at the core of this paper: in Austria the share of organic area grew strongly in the early 1990s and has had a sustained growth since then (Fig. 1). Italy has had a strong growth in the late 1990s, then plateaued in the 2000s, 
before growing again in the 2010s. In France the development started later, increased at a lower rate, with a stronger growth in the 2010 s.

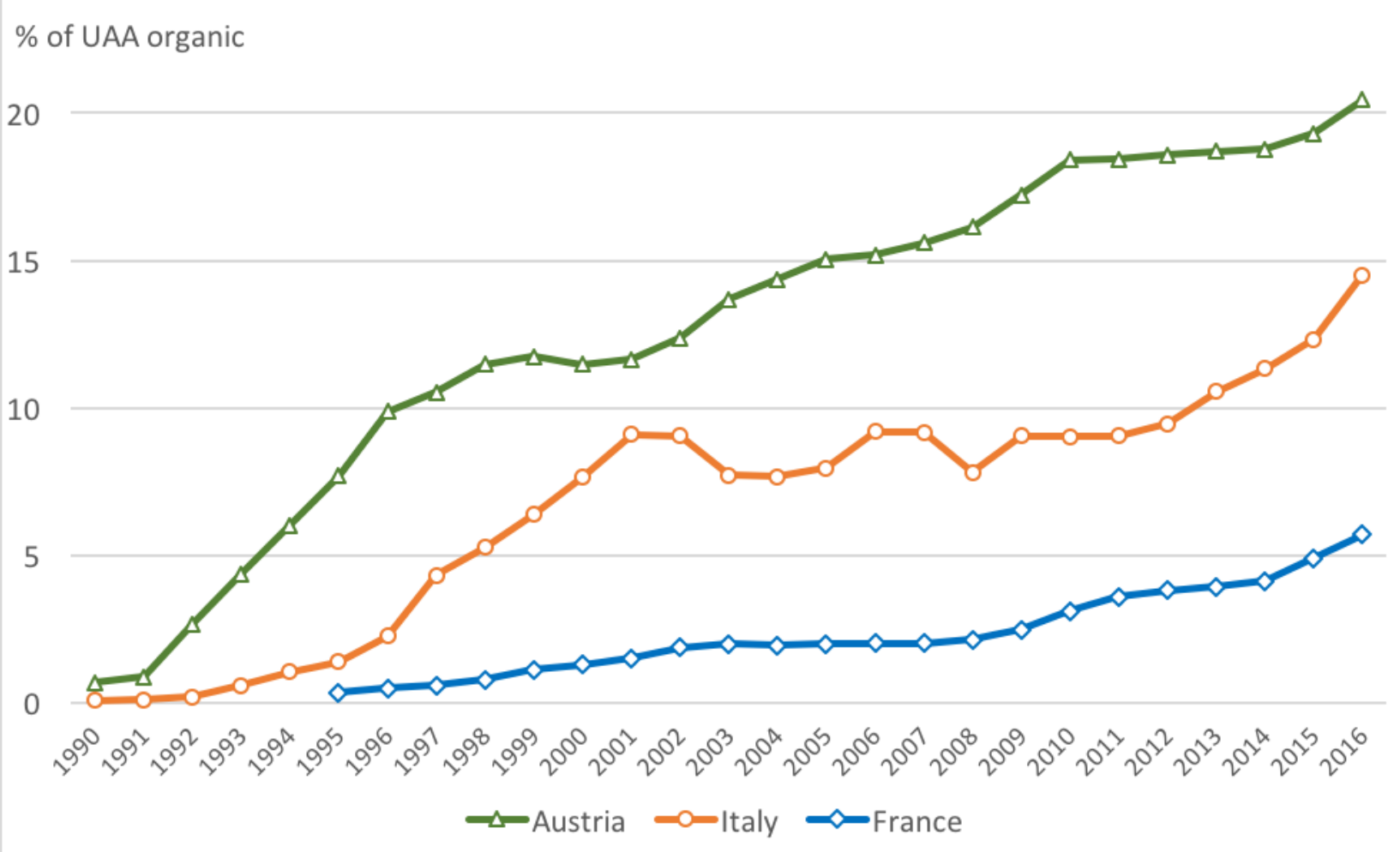

Fig. 1: Share of organic area in the total Utilised Agricultural Area (UAA), for Austria, Italy, and France. While the share of certified organic land at national level hides large variations between production types and regions within a country, it indicates the acceptance of organic farming by farmers, policymakers, and citizen-consumers over time

Sources: Austria: Grüner Bericht (UAA excl. alpine pastures); Italy: ISTAT and Sinab; France: Agence Bio

A number of studies have looked at factors that have influenced the development of organic agriculture. They highlighted the role of agri-environmental programmes, of farmers' perceptions, of legally binding regulations, of the discourses surrounding organic farming, and of the organisation of the value chain. Most studies seek to identify clear cause-effect linkages, i.e. they look for mechanisms that are universally applicable. As a result they may underestimate context-dependency, i.e. the influence of the national circumstances as well as the influence of past events on later developments.

In this paper, we argue that a relational perspective allows a more nuanced understanding of dynamics in agrifood systems, as it understands change as situated, so that to make sense of events they need to be considered within their specific spatial and temporal context. Moreover, the relational perspective points out that if the temporal and spatial context matter, causal mechanisms are not universal but necessarily context-specific. As such, while the influence of a particular factor is real, its explanatory power is limited, for its specific effect can only be understood in a particular constellation. This understanding would limit the usefulness of generalized recommendations and highlight the role of the ability of actors to creatively seize emerging opportunities to induce and sustain change.

We begin the paper by briefly reviewing the literature analysing the development of the organic sector, focusing on studies in Western Europe. We then characterise the relational perspective, and propose an analytical framework that maps out relations between five sets of actors that play a central role in the dynamics of the organic sector. We illustrate the usefulness of this framework through examples from Austria, Italy, and France, as the dynamics of their organic sectors are quite different (Fig. 1), although they have been subject to the Common Agricultural Policy since at least the mid-1990s. In contrasting the three 
countries our aim is not to present a systematic comparison or to comprehensively analyse the dynamics in each country. Rather, we use examples from these three countries to identify the diversity of relations involved, and to highlight the context-dependency of their dynamics. We thus illustrate how various factors related to place and time shape the opportunity context of actors, and how the choices made by collective actors influence future possibilities to build lasting relations. We conclude by discussing the strengths of a relational perspective for understanding the dynamics of agrifood systems as an ensemble of emergent social practices.

\section{Understanding the dynamics of the organic sector}

\subsection{Review of factors influencing the development the organic sector}

A number of studies have looked at factors that have affected the development of the organic sector ${ }^{1}$ in various countries. We distinguish between four bodies of literature which each highlight specific relations that have shaped the organic sector: the agricultural policies, which have provided economic incentives; the impact of relations built through specific institutions; the discursive relations built between organic farming and the dominant norms in agriculture; and finally the values attached to food and thus the relations built with consumers.

Numerous studies have analysed the role of policies that were implemented at EU-level and in individual Member States to promote organic farming. They show that EU policies, especially agri-environmental measures, have been implemented differently, which has had an impact on the relative economic attractiveness for farmers to convert to organic farming (e.g. Lampkin et al., 1999; Padel et al., 1999; Michelsen 2001, 2009; Dabbert et al., 2004; Nicholas et al., 2006; Nieberg and Kuhnert, 2006; Kerselaers et al., 2007; Lesjak, 2008; Zander et al., 2008; Kaufmann et al., 2009; Offermann et al., 2009; Stolze and Lampkin, 2009; Läpple, 2010; Sanders et al., 2011). These studies have identified a range of factors that have influenced the share of certified organic area, including the speed at which EU policies were implemented at national level, the national funds made available for co-funding the agri-environment programme, the absolute level of payment per hectare for organic farming, the payment level for organic farming relative to other agri-environment measures, whether payments were offered only for the conversion period or also for maintenance, whether payments for organic farming were offered on the whole territory or only in designated areas, the funding of accompanying measures (e.g. for on-farm investments, extension services), as well as the consistency in the policy commitment towards organic farming in consecutive CAP programming periods. Beyond shaping the relative economic attractiveness for individual farmers, this literature also showed that policies influenced the development of the organic sector by providing (or not) financial support for organic farmers associations, for research, for awareness raising, and for increasing demand through public procurement programmes (Rech, 2003; Morgan and Sonnino, 2008). This body of literature highlights the role of economic relations for farmers when they make the decision to convert, and more broadly that building relations with policymakers enables the organic sector to access financial resources. It builds on a deterministic perspective, as it presents economic relations - such as payment rates and conditions - as the cause of action.

A second body of literature has looked at how institutions have shaped the organic sector (Kaltoft, 1999; Michelsen, 2001; Vogl et al., 2005; Gibbon, 2008; Moschitz, 2009; Padel et al., 2009; Klein and Winickoff, 2012; Lamine, 2017; Seufert et al., 2017). This literature has pointed out the strengths but also the drawbacks of defining legally binding standards, e.g. compared to less clearly defined alternatives, such as agroecology. It has emphasized that while building relations with policymakers provides legal protection for what can be labelled 'organic', the shift away from self-regulation may lead to a loss of control over the definition of production standards. Moreover, the logic inherent in the audit culture has tended to reduce

\footnotetext{
${ }^{1}$ We use the term 'organic sector' to refer to all actors linked to organic agriculture and food, including: organic farmers, farmers' associations, umbrella organisations, advocacy groups, processors, traders, certifiers, consumers, researchers, and policymakers.
} 
organic farming to those practices that can be easily documented, measured, and controlled, to the detriment of intangible principles and values (Allen and Kovach, 2000; Rahmann et al., 2017; Fouilleux and Loconto 2017a). This literature has also highlighted the key role played by EU regulations in fostering the multiplication of interlocked markets for products, standards, certification, and accreditation services (Fouilleux and Loconto, 2017b). It has also enabled a reductionistic, input-substitution approach to organic production practices, which may make conversion easier for farmers (Lamine, 2011), but may also lead to a 'conventionalisation' of organic farming (Guthman, 2004; Best, 2008; Stassart and Jamar, 2008; Pratt, 2009; Darnhofer et al., 2010). To counter this trend, there is a re-differentiation, with some organic associations seeking to implement a comprehensive approach to organic farming, going beyond market relations to include relations based on values such as fairness and social justice (Home et al., 2017; Rahmann et al., 2017). Overall, this body of literature points out that the material and social relations that are understood as defining organic farming are contested. It highlights that the dynamics of the organic sector are driven by meaning-making processes. The number of actors participating in this process has been broadened when private and legal standards were defined and third party certification implemented. It also shows that dynamics are driven by unexpected side-effects, such as those that emerged from the engagement with regulatory bodies.

A third body of literature has focused on how the relation with broader agrifood discourses has influenced the dynamics of the organic sector. In Western Europe, the modernisation discourse has shaped national agricultural policies since the 1950s (Grin, 2012). This normative discourse focuses on increasing the productivity per worker, plant, and animal, which is to be achieved through enlarging, mechanising, specialising, and professionalising farms (Weis, 2010). The promise of abundant, cheap food should be achieved through industrialising food processing, and through long food supply chains dominated by large retailers (Weis, 2010). As an emerging niche, organic farming needs to engage with and position itself in relation to this broader discourse. As an alternative political project for agriculture, it is seen as a radical break from - and as a form of resistance against - the modernisation of agriculture (Morgan and Murdoch, 2000; Vos, 2000; Reed, 2001; Fouilleux; 2003; Bivar, 2018). Indeed, it builds on different material and social relations to avoid the negative environmental and social impact associated with modernisation. This body of literature contrasts the perceptions of organic farming and of modernised agriculture, not least regarding the role of the farmer, and of agriculture in society (Kaltoft, 2001; Campbell and Liepins, 2001; Kjeldsen and Ingemann, 2009; Lynggaard, 2007; Alrøe and Noe, 2008; Tomlinson, 2008). For example, De Cock et al. (2016) identified three discourses regarding organic farming in Flanders: an 'agro-industrial discourse' that discredits organic farming for its lack of efficiency, portraying organic farmers as eccentric, ideological, and unprofessional (i.e. organic farming is a luddite movement, at a time when increasing yields is necessary, given the imperatives to be competitive on international markets, and the need to 'feed the world'); a 'market discourse' where organic farming is seen as a profitable strategy that meets the demand of certain consumers, but targets only a niche market (i.e. it is not a viable model for all farmers); and an 'agro-ecological discourse' which portrays organic farming as a radical alternative to the modernisation of agriculture, which is seen as socially and environmentally unsustainable (i.e. the emphasis is on protecting soil and water, on trust-based short food chains, and on the preservation of family farms). This body of literature shows that organic farming is understood in relation to conventional farming, i.e. assessed based on whether or not it can address issues that are perceived as problematic in the dominant agrifood discourses and practices.

Finally, a fourth body of literature points to the role of marketing chains and consumer purchasing behaviour in shaping the dynamics of the organic sector. While in Western Europe organic farming initially built on direct producer-consumer relationships, the growing range of organic food found in mainstream supermarkets or specialized organic stores has facilitated access to a wider range of consumers, especially those in urban areas (Padel and Midmore, 2005; Lobley et al., 2013; Thorsøe and Noe, 2015). Engaging with processors, supermarkets, and exporters enabled larger quantities of organic food to be sold, often at a premium price, which fuelled the growth of organic area. These dynamics depend on the extent to which organic production practices, certification, and organic food are perceived as fulfilling consumer expectations (Andersen, 2011; Eden, 2011), or the ability of organic food to induce a 'change of mind' in consumers (Naspetti and Zanoli, 2014). The dynamics of the organic sector are thus also shaped by the 
relations between organic farmers' associations and traders, processors, retailers, exporters. Indeed, getting involved with large retailers may put pressure on organic actors regarding the type and quantities of food products to be produced (Green and Foster, 2005; Desquilbet et al., 2017). While engaging with powerful actors of the conventional food system may bear the risk of conventionalisation (Guthman, 2004; Poméon et al., 2017; Le Velly, 2017), it may also lead to a diversification of the organic sector (Campbell and Liepins, 2001; Kjeldsen and Ingemann, 2009; Rosin and Campbell, 2009; Lamine, 2017). This body of literature thus points towards reflexive social dynamics, as engagement with new opportunities brings about side-effects that are perceived as undesirable by some groups, initiating counter-strategies.

The ample literature on the development of the organic sector in Western Europe has identified a range of influencing factors. However, the differences in the organic sectors between countries indicates that the influence of these factors is not necessarily deterministic, thus making it difficult to identify generalized causal relations. To understand the dynamics of the organic sector, it might be helpful to understand the influencing factors as reflecting relations negotiated between social actors, thus focusing the analysis on why and how relations were constructed differently.

\subsection{A relational perspective}

While there are different strands of relational sociology, what they have in common is the aim of moving from the study of 'social things' to the study of dynamic social processes (Emirbayer 1997; Dépelteau, 2013, 2018a; Eacott, 2018). The focus is thus not on the nodes as independent entities engaging in relation, but with the relations themselves. This implies a move away from accounts stressing the structural constraints on practices, or the agentic abilities of actors to overcome these constraints.

In this paper, we build on a 'deep' or 'process-relational' approach (Dépelteau 2018b), which understands relations as processes, as constituted by flows of action, always dynamic and fluid (Powell and Dépelteau, 2013). A process-relational perspective does not question the relevance of the various factors influencing the dynamics of the organic sector identified in the vast body of literature. However, it points out that actions and their outcomes cannot be understood outside of their specific constellation (Dépelteau, 2015). In other words, both the action and the outcome are intimately linked to that constellation; the action is thus not in itself the cause of the outcome. For example, the direct payments offered to farmers are not the 'cause' of the conversion. Rather, the payments are an effect of relations built around agriculture as a provider of public goods and by citizen-consumers valuing specific production practices. These various relations intermingle to create a constellation that facilitates conversion. In the process-relational perspective, there is no search for 'mechanisms' that would be universally applicable, as these assume a clear cause-effect link, irrespective of context. The aim is thus not to identify explanations based on seeming similarities between cases. Rather, the focus is on unravelling context-specific processes, that emerge from interactions between social actors, showing how over time these relations unfold unpredictably, highlighting the complexity and fluidity of real life.

A relational perspective conceptualizes the organic sector as constituted through the relations in which it is engaged. While the organic sector can be seen as a distinct 'entity', it has no pre-relational 'essence'. It does not exist 'as such', outside of specific relations. In other words: the organic sector of a country is what it is and does what it does because it interacts with specific others in specific ways (see Dépelteau 2018b:513). Not only does the organic sector emerge through these relations, it also co-produces these relations and is thus not determined by them. Indeed, relations are always reciprocal, i.e. in a relation each party adjusts its actions to the actions of the other, and no party has complete control over the relation (Dépelteau, 2013). This reciprocity does not mean that the relations determine either or both parties, but it means that we cannot understand or explain e.g. what the members of an organic farmers association are doing without taking into account e.g. the group of conventional farmers with whom they are interacting. As such no actor is determined, and each actor is always engaged in a range of (partly competing) relation building processes.

The social context is not so much a (fixed) structure that determines options and acts causally, it is more an interactional field (Dépelteau, 2018a:16). Understanding the dynamics of organic sector in a country is thus 
not about identifying one or a few causal factors (e.g. payment levels, legal frameworks, or the structure of the value chain), but about the social relations that were built and understanding why they were built and maintained in that particular way. The organic sector is thus understood as emerging out of relations, which are constantly worked at, redefined, weakened, rebuilt, and threatened by competing relations. This includes the meaning of organic production practices in relation to conventional agriculture, and the meaning of organic food in relation to other alternative food qualities and to broader cultural values tied to food. It also includes the relations built to broad issues that are salient in a society at a certain point in time, such as the concern for environmental protection or for public health in the face of a food scare.

Our approach of the organic sector as a vibrant and evolving social process based on ever-renegotiated relations enables a focus on fluidity and dynamics. The outcome of these ever changing relations is undetermined, as actors can influence, but not control a relation. This does not diminish the potential of actor's improvisation, virtuosity, reflexivity, creativity, and choice (Tsekeris, 2013). Indeed, this perspective shifts the attention from seemingly stable structures towards the role of actor's response to events, of their ability to recognize emerging opportunities within their specific context.

\subsection{The conceptual framework}

We propose to conceptualize the organic sector as emerging based on the relations that are built, i.e. how actors engage with organic farming practices, what meaning they attribute to them, how they use them to build ties with other social actors, what relations stabilize over time through on-going work, and what conflicts arise and how they are resolved (if at all). For understanding the dynamics of the organic sector at the national level, we propose to focus on relations between five sets of actors: the organic farmers associations, the State, established or mainstream farmers associations, advocacy groups engaged in politicizing the agrifood system, and various actors along the food value chain (Fig. 2). All five sets of actors may interact more or less, exchanging information, ideas, values, resources, enabling them to follow coordinated strategies or to engage in protracted conflicts. Moreover, these five sets of actors engage in relations within a broader context, especially the national cultural values which shape the discourses surrounding the agrifood system, as well as influence which issues are perceived as salient and how they are framed. The actors also have to respond to events such as food scares (see Knowles et al., 2007) which may create opportunities to weaken some relations and strengthen others, thereby affecting the organic sector.

Broader context, incl.:

- National cultural values and governance structures

- Salient issues (e.g. concerns regarding the environment or food quality)

- Events (e.g. GMOs, food scares, agricultural crises)

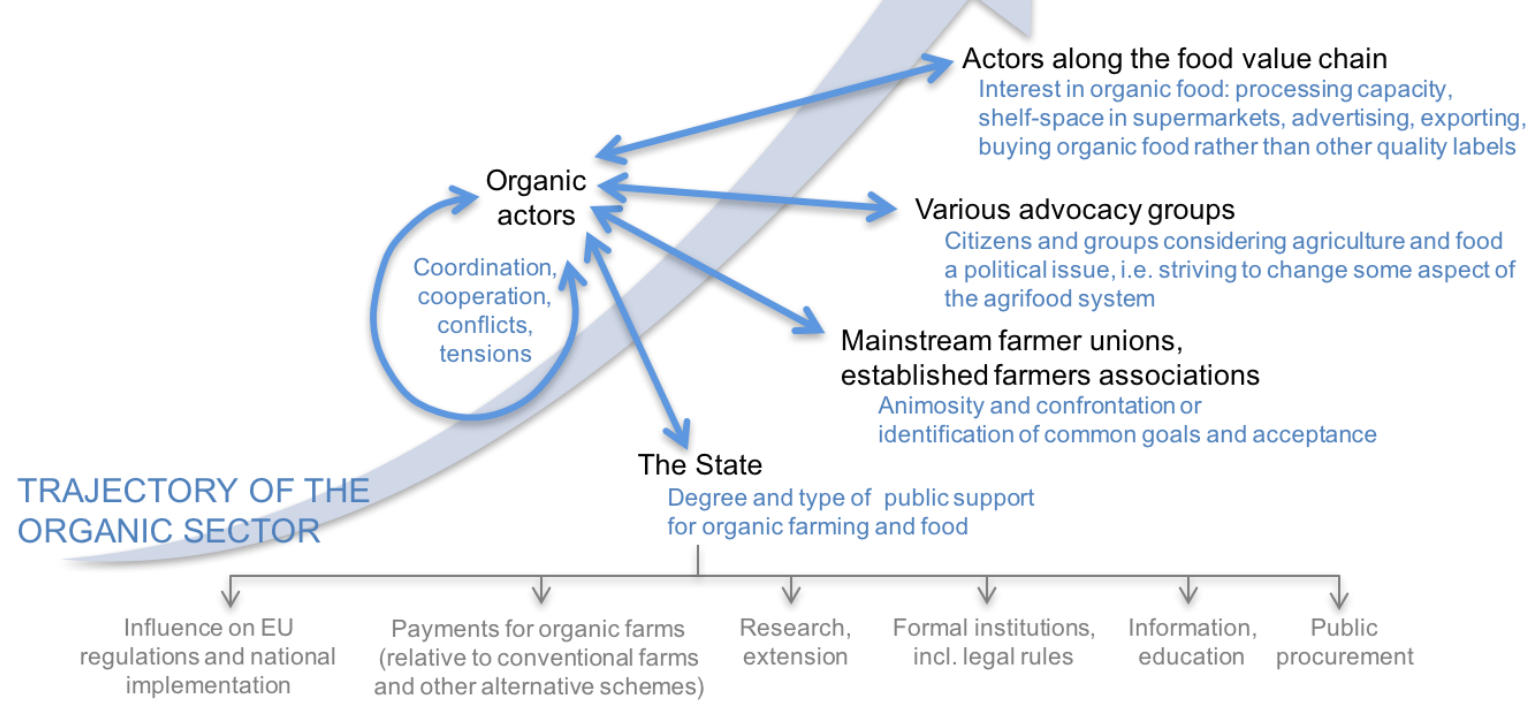

Figure 2: The dynamic of the organic sector is shaped by the ability to actively build, define, and maintain diverse relations with diverse actors. The double-headed arrows indicate that the relations between actors are reciprocal, 
each actor both influences and is influenced by other actors. For the sake of clarity, we have not included arrows to indicate relations within and those between actors (e.g. between the State and established farmers unions). The order in which the actors are included along the trajectory of the organic sector is arbitrary, and it is likely that which actor plays a key role earlier or later will depend on the national context.

While for analytical purposes, it is very helpful to distinguishing between these five sets of actors and to distinguish among specific relations (Fig. 2), we are aware that actors are often hybrids (Ilbery and Maye, 2005) and that the relations between them vary. For example, while we distinguish between the State and mainstream farmer unions, in many countries agricultural policy tends to be heavily influenced by the interests of these farmers union (Jordan et al., 1994), so that their interests and rhetoric might be quite similar. Figure 3 thus illustrates the intricacy, complexity and hybridity of the relations among the actors in the field.

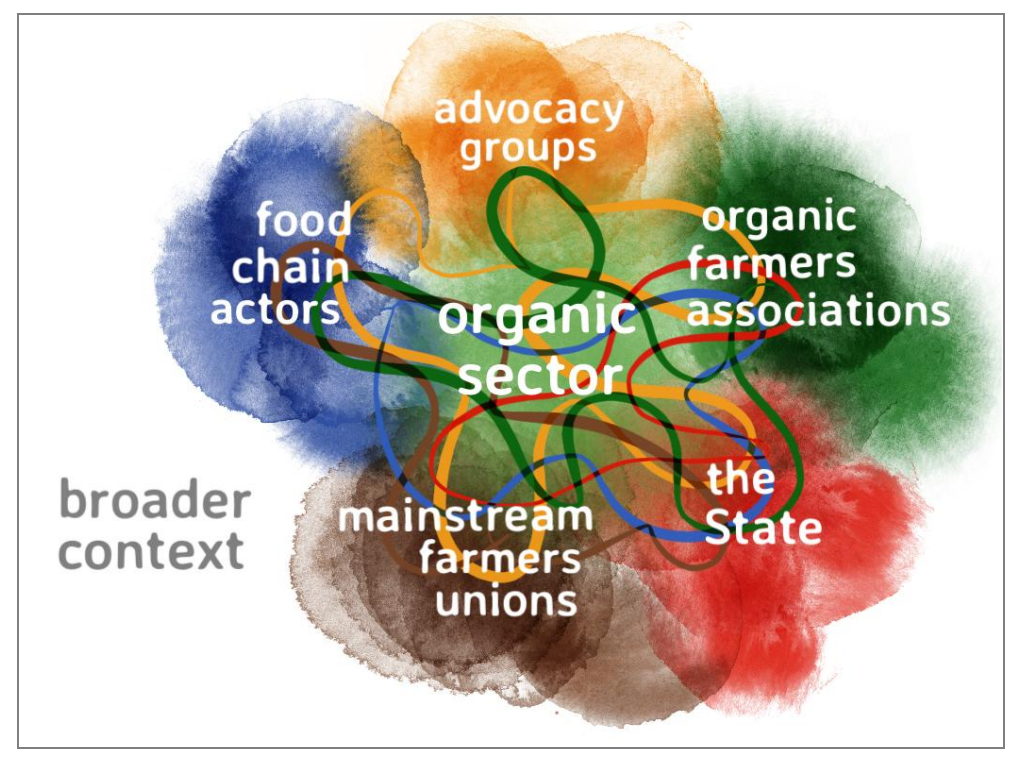

Figure 3: The organic sector is understood as an evolving social process, as emerging from the relations built, redefined, and maintained between five sets of actors. The different shades within each set of actor indicates that they are not homogeneous groups, i.e. they have diverse objectives and intentions. All actors concurrently engage in a number of multi-directional relations. These relations unfold within a broader context, which includes national cultural values, salient issues (e.g. concerns about the environment or the quality of food), and events (e.g. anti-GMO protests, food scares, agricultural crises)

Clearly, the organic sector is not constructed at will by one set of actors. While social actors may engage in action with the intention to purposefully shape the organic sector, these actions may exceed or fall short of their intentions (see Powell, 2013). No actor controls the dynamics of the organic sector on its own, no matter how unequally power is distributed. Yet, through each action, actors build and rebuild their knowledge of the field in which they are engaged, and use this knowledge to orient themselves, to refine their expectations of others' behaviour (Dépelteau, 2013).

The process of building and modifying relations is guided by an empirical and contextualized problem. The ability of the organic sector to address this problem will be shaped by how this problem is defined, i.e. what actors have successfully tied specific relations to the problem, thus defining it. These relations emerge from past conflicts, strategic alliances, dominations, and collaborations. Social actors are thus understood as renegotiating their relations with others, not least by manipulating common understandings, by reconstructing narratives (King, 2000; Eacott, 2018; Lehtimäki, 2018). Indeed, relations not only have practical materiality, they also convey meaning, a meaning that is created and renegotiated through a coevolutionary dynamic (Chia, 1999). The relations that shape the dynamics of the organic sector can thus be continually enriched with newer and novel meanings, understandings, and applications, while at the same time alternate meanings are dropped or pushed into the background.

As relations unfold over time, the historicity of relations plays a key role. This temporal context is not an external variable, rather it is embodied and embedded in activity through the perception of the actors (Eacott, 2018). Indeed, interactions at a specific time are always connected to various past experiences 
through dynamic and heterogeneous memories, knowledge, views, through long chains of interactions (Dépelteau, 2015: 14).

\section{Comparing relations that shaped the dynamics of the organic sector in Austria, Italy, and France}

\subsection{Relations between organic farmers associations}

While the relations between organic actors became more complex as the diversity of actors involved increased, the organic sector in the three countries emerged with the first organic farmers associations. While all pioneers of organic farming shared their opposition to the modernisation of agriculture, there were differences regarding production practices (e.g. between organic and biodynamic practices), the vision and values they attached to organic farming (e.g. relative emphasis of focus on soil health and on preserving traditional farms), and the marketing strategies deemed acceptable (e.g. only through direct marketing, or also engaging with supermarkets). Given that 'history matters', in this section we focus on the emergence of the organic sector, and thus on the relations initiated between and by organic farmers associations.

In Austria, the first organic farmer associations were formed in the 1960s and by the mid-1980s there were some 12 associations (Jurtschitsch, 2010). Following demands by the associations to protect organic farmers and their products against fraud, production standards for organic crop production were included in Austrian Food Codex (chapter A8) in 1983 (standards for animal production were included in 1990). One association, active in the whole country, had by far the largest number of members: in 1991, $73 \%$ of organic farmers were members of the 'Ernte' association (Pirklhuber and Gründlinger, 1993). This dominance persisted, as in $2003,87 \%$ of organic farmers who were member of an association (62\% of all organic farmers) were with 'Bio Ernte Austria' (Schermer, 2005). The relatively strong concentration within the 'Ernte' association enabled effective action at several levels: to provide advice and support to farmers through local groups, to be a unified partner for policymakers, and to bundle the commodities from farmers to achieve the quantities needed to supply supermarkets. In 2005, under the pressure of the Ministry of Agriculture, the previously existing two umbrella organisations were merged into one, named 'Bio Austria' (Jurtschitsch, 2010). The fact that there had been one dominant association, which later also dominated the single umbrella organisation, enabled settle various contentious issues internally, and to speak with one voice with policymakers.

In Italy there was a strong regional disparity: associations in the northern and central regions (especially Emilia-Romagna and Tuscany) emerged in the 1950s and were committed to the principles of biodynamic farming, while in the southern regions (esp. Sicily and Sardinia), organic farming took roots in the 1990s with a focus on export markets (Zanoli et al., 1999; Paltrinieri and Spillare, 2015). The largest association, the Associazione Italiana per l'Agricoltura Biologica (AIAB) was founded in 1988 and includes farmers, advisors and consumers. Although some of the nine producer organisations aimed at providing extension services to organic farmers, most were merely lobbying and cultural associations (Compagnoni et al., 2000). In 1992 the Federazione Italiana per l'Agricoltura Organica (FIAO, since 2005 the Federazione Italiana Agricoltura Biologicia e Biodinamica - FederBio) was founded as an umbrella organisation, to represent the sector at a political level and to inform the public about organic farming. However, in 2007 AIAB, followed by other associations, left FederBio, among other due to conflicts over the ways to handle the coexistence with GMOs and the type of alliances that organic producers might build to develop the sector (Zanoli, 2007).

In France, the organic farmers associations have been entangled in long-lasting conflicts (Bivar, 2018). Initially the tensions were related to the ideological shift among the organic actors: until the 1950s they were mostly agrarian, reactionary and close to the extreme right, but starting in the 1960s the majority defined themselves as left-wing, anticapitalist and anticentralist (Leroux, 2011, 2015). In the 1960s there were also tensions regarding production practices. For example, 'Lemaire et Boucher' promoted its own 
method and emphasised one particular input which it sold, while 'Nature et Progrès' was more open and welcomed farmers who followed either organic or biodynamic practices. 'Nature et Progrès' defined a formal standard in 1972, which was among the first in Europe, and played a key role in promoting organic farming in France throughout the 1970s. As a result, 16 organic farmers organisations were set up, often with regional particularities. Around 1980, under the umbrella of the State, the various organic farmers associations engaged in a laborious process to define a common national production standard, mired by intense conflicts between associations. The national standard was published in 1982, despite the fact that at the last minute the standard was rejected by 'Nature et Progrès' who refused third party certification. In the 1990s, the associations started to cooperate, and since 1998 the Fédération Nationale de l'Agriculture Biologique (FNAB, created in 1978) is their main representative. However, the tensions between 'Nature et Progrès' and the other associations have endured, as it criticises them for being too strongly oriented towards the industry. 'Nature et Progrès' remains a private trademark and promotes its Participatory Guarantee System. However, while Participatory Guarantee Systems are widespread outside Europe, it is currently not a legally recognized certification system in the EU (Fouilleux and Loconto, 2017; Home et al., 2017).

In the three countries a range of organic farmers associations emerged in the 1950s and 1960s, striving to develop different production relations than those promoted by the modernisation of agriculture. In the 1980s and 1990s, as the number of organic farmers grew and as the environmental impact of modernised production practices became more visible, the State started to get involved and coerced the organic farmers associations to organise and speak with one voice. This put pressure on the association to intensify and formalise their relations, by creating umbrella organisations, and - in Austria and in France - by agreeing on national standards. Differences, e.g. due to regional specificities, or commitment towards specific values or production practices were not always easy to overcome, leading to conflicts, not all of which could be resolved.

\subsection{Relations with the State}

To build and maintain efficient relations with policymakers, it is helpful if organic agriculture is perceived as offering a solution to a problem that is salient in the public discourse and that puts pressure on policymakers to act. In Austria these relations were built early and have remained strong, as organic farming was perceived as a way to address the social and environmental impacts of modernised agriculture. In Italy and in France these relations have been weaker, as policymakers saw organic farming primarily as a niche market rather than as a way to protect public goods, weakening the rationale for providing public funds.

In Austria, in the early 1980s, the State formally engaged with organic farming by commissioning and funding research to seek scientific evidence for the claims made by organic farmers associations (Pirklhuber and Gründlinger, 1993). In the late 1980s, with its increased presence in the public discourse, organic farming was advanced by a number of actors as one approach to simultaneously address two acute policy challenges: reduce produced quantities (and thus the budgetary burden created by the need to subsidise exports due to overproduction), and reduce the environmental impact of intensive production methods (Pirklhuber and Gründlinger, 1993; Ortmayr, 2007). Thus, when in 1987 the Minister of Agriculture introduced the 'eco-social agricultural policy', it explicitly referred to organic agriculture (Ortmayr, 2007; Schermer, 2008, 2014). This commitment as part of the new agricultural policy was followed up by providing resources to strengthen the organic sector, including funds for organic farmers associations. In 1988 a permanent post was created at the Ministry of Agriculture to coordinate issues related to organic farming. Starting in 1990, payments were offered to farmers during the conversion period, and since 1992 all organic farms have been eligible for payments, both during the conversion period and for maintenance (Groier, 2005). Moreover, with the accession to the EU becoming more likely ${ }^{2}$, and with the implementation of the McSharry CAP reform, organic farming was seen as one way to secure the income of

\footnotetext{
${ }^{2}$ Austria joined the EU in 1995
} 
mountain farmers (in addition to the compensatory payments for less-favoured areas). These mountain farms, mostly extensive dairy farms, were seen as 'almost organic anyway', not least as in the early 1990s there was no regulation for organic animal production at $\mathrm{EU}^{-l e v e l}{ }^{3}$ so that the national standards would be applicable.

In Austria, this policy commitment towards organic farming has remained strong through the various CAP programming periods. In the current period (2015-2020), 37\% of the funds for the agri-environment programme are ear-marked for organic farms. The Ministry of Agriculture justifies this support through the contribution that organic farming makes towards preserving biodiversity, protecting soils, surface water, ground water, and the climate (BMFULW, Bioaktionsprogram 2015-2020). The State also funds various activities that benefit the organic sector, including research, information and awareness raising campaigns, and education in vocational agricultural schools. The commitment towards the continued development of organic farming is also expressed in the official aim of the Ministry of Agriculture to maintain Austria as 'number one in the EU' regarding the share of organic land, as documented in all Organic Action Programmes since the first one in 2001. Moreover, organic farming is perceived as a way to add value to farm products, and as strengthening the competitiveness of agricultural products from mountainous areas, thereby maintaining family farms (Sassatelli and Scott, 2001). The policy commitment towards organic farming is thus enabled by broader values around farming, which is seen as fundamentally multifunctional, i.e. as fulfilling not just economic, but also ecological and cultural functions.

In Italy there were attempts to seek State support for organic farms in the 1980s, which was advocated by environmental organisations and the Green Party, however these attempts failed (Zanoli et al., 1999). While the national government was generally supportive of EU regulations and directives, it has been reactive rather than proactive in their implementation (Sassatelli and Scott, 2001). Agriculture policy is devolved to the regional level, and the regional governments played an uneven role in promoting organic farming. In particular, Tuscany and Emilia-Romagna approved funds to promote organic farming through their agri-environment programme (Compagnoni et al., 2000). However, in 2000 the Italian government promoted demand for organic food by introducing a law that supports organic meals in schools, and the Italian case became an example of the 'school food revolution' (Morgan and Sonnino, 2008; Filippini et al., 2018). This law was implemented following demonstrations mounted by green associations, who drew attention to the food served to children in schools. They demanded that this food be of high quality, be sourced from local farmers, and be produced using fewer chemicals, which were seen as dangerous for the children's health and for the environment (Sassatelli and Scott, 2001). In 2001 a law (228/01) was passed, that defined 'quality agrifood districts' and 'rural districts' which aimed to promote multifunctionality and traditional products (Bartoli and De Rosa, 2010). While such a law did not directly promote organic farming, it created conditions which were also favourable for organic farmers. In 2005 the general support of the State for the organic sector was expressed through the publication of the first National Plan for Organic Agriculture. Its specification of four axes shows that the State expected market actors to play an important role in developing the organic sector.

In France, the modernisation discourse has been hegemonic since the 1950s and the Ministry of Agriculture has favoured input-intensive agriculture (Muller, 1984; Fouilleux, 2003; Ansaloni, 2015). This policy is legitimized by the myth that French agriculture has a 'vocation' to export, especially cereals and wine. In this output-oriented context, organic practices are perceived as lacking as yields are lower. Moreover, the market-orientation implies that organic food needs to demonstrate its competitiveness through the market. The State has thus focused on organizing the market by giving organic production standards a legal status in 1982, enabling organic food to be differentiated from other quality labels, such as 'label rouge' and geographical indications (see Ansaloni and Fouilleux, 2008). Direct support has been marginal and

\footnotetext{
${ }^{3}$ The European standards were defined in two steps: the initial regulation (EEC) 2092/1991 covered only plant production, while standards for animal production were defined later, through Regulation (EEC) 1804/1999. Both were superseded by Regulation (EC) $834 / 2007$ on 'organic production and labelling organic products'. The latest Regulation (EU) 2018/848 has been adopted in May 2018 , and is expected to take effect in January 2021. Beyond the legal definition of organic production, Member States were given the possibility to offer direct payments to organic farmers since 1992, through 'accompanying measures' (later agri-environment measures), which were introduced though Regulation (EEC) 2078/1992.
} 
intermittent. Payments to organic farmers have been offered since the introduction of the agrienvironment scheme in the CAP, but only a very small budget has been allocated to it: $0.2 \%$ of total CAP support to France in 2000 , and $1 \%$ in 2013 . Also, support has been offered primarily for the conversion period. Support for maintenance was introduced in 2008, but in late 2017, the State announced that due to budgetary constraints, payments for organic farms would again be limited to the 3-year conversion period, starting in 2018. This sudden reorientation, the general lack of continuity, and the constant changes in the administrative procedures and programmes, has made access to direct payments challenging for farmers.

The lack of commitment of the State to organic production methods can also be illustrated by the ambitious 'agroecological project for France', which was launched in 2013 by the Ministry of Agriculture. While it included organic agriculture as one way to 'produce differently' it was listed as one among a range of agricultural models, not as an apex practice (Lamine, 2017). The poor relations with the State are also reflected in the French agronomic research policy, which for decades has not considered organic agriculture as a production method worthy of exploration (Bellon et al., 2000). This was expressed recently in a report compiled by the Institut National de la Recherche Agronomique (INRA), which compared the performance of conventional and organic agriculture (Guyomard, 2013). Some of the recommendations in this report, especially to consider the option of allowing synthetic pesticides in organic farming as a way to increase its productivity and thus its competitiveness, led to an intense controversy ${ }^{4}$ within INRA, as well as between the organic sector, the State, and INRA (Lamine, 2017).

Regarding relations between organic agriculture and the State, there are strong differences between the three countries. While the Austrian organic sector was able to build and maintain strong relations with the State, in Italy the relations may be characterised as generally supportive but passive, while in France they are reluctant, lacking both continuity and commitment.

\subsection{Relations with mainstream unions and established farmers associations}

The dominant farmers' unions tend to be aligned with the modernisation paradigm which encourages large-scale, input-intensive farming. However, there are also farmers' associations that aim to maintain small farms and extensive farming practices. Building relations with such established actors may be a valuable resource for the organic sector. Indeed, in Austria and in Italy, organic actors were able to build alliances with mainstream farmers unions or associations. This was enabled by identifying a shared goal: the maintenance of family farms and traditional production methods, even if the underlying justification was different in the two countries. In France, relations were more difficult to establish, the notion of 'family farm' having been assimilated in the modernisation paradigm and seen as fully compatible with large-scale farming (see Muller, 2000). Only recently common ground is emerging with associations advocating 'peasant farming'.

In Austria the organic farmers associations joined forces with the association for mountain farmers in the early 1980s (Posch, 2013). This association carries some weight, as about $40 \%$ of Austrian farms are classified as mountain farms. The alliance helped the organic farmers association to acquire the skills needed to interact with policymakers. Importantly, the dominant organic farmers association chose a moderate position in its rhetoric to avoid antagonizing powerful actors, such as the main farmers union (the Bauernbund) or the Chambers of Agriculture. The emphasis was put on identifying a common goal: the maintenance of family farms. Indeed, while the dominant farmers organisations endorse the modernisation of agriculture, they are still committed to maintaining family farms, which are seen as the backbone of a living countryside, and as providing important services for the tourism industry. The contradiction between modernisation and traditional farming is overcome through territorial distinction: in less favoured areas, organic farming is framed as a continuation of the traditional way to farm, while in areas where intensive production practices are feasible, scale enlargement and competitiveness are promoted (Schermer, 2008).

\footnotetext{
${ }^{4}$ See the INRA website „L'agriculture biologique en débat“ at: http://institut.inra.fr/Missions/Eclairer-les-decisions/Etudes/Tousles-dossiers/L-agriculture-biologique-en-debat
} 
As a result, organic farming has never been framed as opposing conventional agriculture, or as a critique of it. Rather, it is 'just another' way to farm, suitable for some farms, especially those situated in areas where the modernisation of agriculture is not seen as feasible, given that productivity is constrained by steep slopes, low average temperatures, and a short growing season (Schermer, 2014). However, as the domestic demand for organic products increased and the marketing channels were well established, organic farming became attractive to a wide range of farms, and a number of large farming estates converted to organic farming. As the owners of these estates are influential, these conversions not only influenced the public rhetoric of the dominant farmers union, it also reinforced the general perception by farmers that organic farming is a production method that is suitable for a wide range of farms, i.e. not restricted to small mountain farms.

In Italy, organic farming was able to build an alliance with Coldiretti, the largest Italian farmers union, in the framework of the struggle to defend the Italian gastronomic heritage (see next section). This heritage relies on extensive production methods, local biodiversity, artisanal processing, and small manufactures. In the 2000s, Coldiretti thus abandoned the modernisation discourse and is the only Italian farmers union explicitly against GMOs. It proposed a new business model for farming, based on multifunctionality and the support for tradition, locality, and family farming (Brunori et al., 2013), principles that are well aligned with organic farming.

In France, for decades alliances between the organic farmers associations and most other farmers unions were not conceivable, because their visions were antithetical: the organic farmers denounced the modernization paradigm defended by the others, while the unions considered organic farmers as backward-looking and sectarian. The dominant farmers' union, the Fédération Nationale des Syndicats d'Exploitants Agricoles (FNSEA) was born with the modernisation discourse and remains strongly attached to increasing productivity through the use of pesticides and mineral fertilizers. For decades the FNSEA has considered organic farming as a remnant of the past, as not productive enough. When organic farming began to develop in response to citizens' environmental concerns, the FNSEA launched the competing concept of 'Agriculture Raisonnée' ('reasoned agriculture'). This is a far less demanding standard which claims to use chemical inputs in more 'reasonable' ways, but in effect does not go beyond the legislation on good agricultural practices. Given the FNSEA's influence on policy decisions through the so-called 'cogestion' (co-management of the French agriculture sector, see Jobert and Muller, 1987; Muller, 2000), it ensured that Agriculture Raisonnée became legally recognized as a third party certified standard in 2002, allowing it to compete with organic farming in the eyes of the consumers.

The modernisation paradigm is so strong in France, that even the left-wing farmers union, the Confédération Paysanne, has historically been very critical of organic farmers. While it strongly opposed the FNSEA on social and economic issues, its views on production methods and technical issues were similar, as both promoted the modernisation of agriculture (Fouilleux, 2003). However, since the 2000s the situation is changing. The Confédération Paysanne has increasingly advocated a multifunctional agriculture and promoted "peasant farming". It is much more open towards organic farming, not least due to the increasing number of organic farmers among its members. Similarly - although to a lesser extent - an increasing number of farmers who are members of the FNSEA have converted to organic agriculture, so that its discourse cannot be as aggressive as it used to be. The FNSEA now argues that models should not be opposed, and that organic agriculture is a niche that can be profitable for some farmers. Services and support for organic farmers are now offered by most mainstream farmers unions, cooperatives, and Chambers of Agriculture (de Silguy, 2015; Gangneron, 2015). This reluctant support takes place in a broader context, where low world market prices for conventional products and high prices for inputs have led to intense crises in the milk, beef, and pork sectors since 2015. Reports of bankruptcies and suicides of conventional farmers have repeatedly made headlines in French newspapers. This contrasts with the reports of success stories of organic farmers selling at higher prices on local markets and securing comparatively comfortable incomes. These media reports indicate a shift in the perception of organic agriculture, and contribute to the recent increase in the number of farmers who are starting their conversion (Bouttes et al., 2018). Taking into account these recent developments, the dominant actors no longer reject organic agriculture, they now want to take part in its definition. This leads to renewed 
tensions with the FNAB, which seeks to remain the main interlocutor, and advocates a definition of organic agriculture close to its ethical and political origins, rather than one only based on the market.

The examples from the three countries show that the organic sector may be strengthened if organic farmers associations can build alliances with established farmers unions or farmers associations. Such relations provide strategic knowledge on how to navigate legal institutions, and strengthen the legitimacy of organic agriculture. In both Austria and Italy, relations were forged based on the shared commitment to traditional family farms. In France, the modernisation paradigm has only recently come under pressure, following protracted crises on agricultural markets. Faced with an increasing number of organic farmers in their own ranks, the dominant unions and associations have had to tone down their critique of organic agriculture, which may open opportunities for new relations.

\subsection{Relations with advocacy groups}

A number of advocacy groups aim their political criticism at the modernisation of agriculture, pointing out its negative impact on environment, its poor animal welfare record, its contribution to the erosion of cultural heritage, its impact on the social cohesion of rural areas, or the relation of modern agrifood systems with various public health issues. These issues may be a common ground, which can enable relations with a range of actors and strengthen the organic sector. This may be illustrated through the alliance between organic farmers associations and the anti-GMO campaign in Austria, and between organic farming and the Slow Food movement in Italy. In France such relations are only beginning to emerge.

Austrian citizens are among the most vigorous opponents of the agricultural application of biotechnology in the EU (Torgersen and Seifert, 2000; Sassatelli and Scott, 2001; Seifert, 2009). In 1996 this opposition led to a general media campaign against genetically modified food and plants, and eventually to a complete ban on GMO cultivation in Austria. Organic farmers associations kept a low profile in the public arena, mostly because they did not have the resources or skills to stage large public events. But the associations successfully built relations with Greenpeace and with various groups campaigning for food that is 'free from GMOs'. In this campaign, the protection of organic farming was a core argument to pre-empt the cultivation GM crops (Seifert, 2009). Indeed, there is a high number of organic farms and they are spread throughout the territory, so that to ensure 'coexistence', the area ineligible for GMO cultivation is vast. The campaign was so successful, that since then, no public decision-maker or official from the dominant farmer union dares speak out in favour of GMOs (Seifert, 2009).

In Italy, public opinion had turned against the modernisation of the agrifood system, especially following the BSE crisis in the mid-1990s. The general feeling was that modernised agriculture had not ensured safe food, and that standardized mass-produced food had led to a homogenization of taste. Above all, it was seen as threatening traditional and artisan products, and leading to a loss of regional identity (Murdoch and Miele, 1999; Sassatelli and Scott, 2001; Tregear et al., 2007). Subsequent activism was aimed at revaluing traditional foods and defending Italy's gastronomic heritage. This boosted support not only for traditional farming practices and artisanal processing, but also for organic agriculture (Brunori et al., 2013). In particular through their alliance with Slow Food, organic farmers gained visibility and legitimacy (Brunori et al., 2013). Organic agriculture has also been promoted by the Pesticide Action Network, as a way to ensure a glyphosate-free diet. Moreover, some organic farmers associations interact with civic movements such as Gruppi di Acquisto Solidale (Solidarity Purchasing Groups). However, these forms of Community Supported Agriculture tend to focus on food produced locally, using traditional varieties, and on fairness in producerconsumer relations, rather than specifically promoting organic production practices (Paltrinieri and Spillare, 2015).

In France, the relations between organic farmers and environmental activists have been weak historically. For example, the Fédération Nationale de l'Environnement, the main umbrella for French environmental associations, has always defended so-called 'productive' agriculture and has carefully avoided to openly oppose the FNSEA due to its powerful position (Ansaloni, 2015). Recently, the high quantities of pesticides used in France have received increased media attention, and many environmental activist organisations (e.g. Générations Futures, Greenpeace) have clearly voiced their support of organic agriculture. The rise of 
public debates around pesticide use may well have contributed to the recent rapid growth of organic consumption in France, which has more than doubled between 2010 and 2016 (Agence Bio, 2017). There is also a growing awareness of animal welfare issues, which until recently were absent from public debates. Associations advocating for direct relations between producers and consumers may also be potential allies. Highlighting the link between health and food, they have organized alternative food trading networks. However, so far there are few formal relations with organic agriculture. For example, production practices in the AMAP network (Association pour le Maintien d'une Agriculture Paysanne, i.e. association for the maintenance of peasant agriculture) are de facto organic (and a number of producers are third party certified) but many AMAPs have opted for Participatory Guarantee Systems and thus do not formally require their producers to be certified (Lamine et al., 2012). Similarly, another successful alternative food network, 'La Ruche qui dit Oui' promotes local products, but most of them are not organic (Rodet, 2014, 2017). More generally, in France 'local' is often successfully put forward by conventional agricultural actors as a way to escape the debate on production practices and pesticide use (Pahun, 2018).

The examples of the anti-GMO-campaign in Austria, or the relations with 'slow food' activists who strive to defend Italy's gastronomic heritage, show that win-win situations can be built between organic actors and other civic movements. Through such alliances, organic actors have an opportunity to convey the relevance of organic farming, i.e. its ability to address a range of concerns citizens may have about the agrifood system. However, since the early 2000s, 'local' has been an increasingly important attribute for food, competing with 'organic' for the attention of environmentally and health conscious consumers. In Austria 'organic' was well established by the mid-2000s, and organic and local were often perceived as going together. In Italy and in France the growing importance of 'local' as an attribute at a time when 'organic' was not well established, may weaken the ability of organic actors to build relations with advocacy groups and various forms of Community Supported Agriculture.

\subsection{Relations with actors along the food value chain}

Going beyond direct marketing and engaging with processors, exporters, and retailers has enabled selling larger quantities of organic food, thus shaping the organic sector. In Austria organic farmers engaged in relations with conventional retailers very early. This relation enabled access to a wide and well established distribution network, as well as to benefit from the advertising power of retailers. In Italy exporters played an important role, whereas in France relations were mostly established with specialist retailers.

In Austria, the dominant organic farmers association early on decided to cooperate with a major retailer, initially to market organic fresh milk and dairy products (Schermer, 2008). While there were reservations regarding potential power differences, in the mid-1990s the relation was constructed as being of mutual benefit. Indeed, the organic farmers association was interested in securing a premium price for the rapidly growing number of organic dairy farmers, and was aware that the quantities of milk produced exceeded what could be sold through direct marketing. The retailer saw organic products as a way to ensure the loyalty of its customers, and thus as a strategy to cope with the impact of EU accession, i.e. the expected

competition from foreign retailers and the flood of cheap foreign food (Schermer, 2014). As Austrian consumers were anxious that EU accession would reduce the quality of food, offering domestic organic food was a way to address the question of trust and maintain consumer confidence (Sassatelli and Scott, 2001). 'Organic' and 'produced in Austria' was thus successfully linked in the public imaginary, and was seen as a way to oppose the 'intrusion' from outside; buying organic food was thus a way for Austrians consumers to contribute to the maintenance of distinctive national values and traditions (Felt, 2015).

The unique position of organic food was reinforced in the late 1990s by addressing Austrian consumer's strong aversion of GMOs. Indeed, only organic food could certify that no GM crops were used in plantbased food, and that products of animal origin were produced without GM feed. Thus organic food was the first choice for consumers who wanted to be certain that their food was 'GMO free' (Torgersen and Seifert, 2000; Sassatelli and Scott, 2001). Given the positive response by consumers, the supermarket chain increasingly defined itself through its organic brand 'Ja!Natürlich', which is now the best known food label in Austria. Other retailers followed suit and created their own organic brands. Retailers thus created for 
themselves an image as guardians of consumers' interests, responding to the increasing demand for locallyproduced and 'unadulterated' food through establishing organic brands, promoting them in ongoing advertising campaigns (Torgersen and Seifert, 2000). As a result, organic food has been successfully linked to 'consumer patriotism', which conveys the 'moral duty' of the consumer to support Austrian farmers, protect the environment, and ensure animal welfare (Sassatelli and Scott, 2001). The 'naturalness' of food produced domestically is conveyed not least through the media, which are replete with "visual discourses of untouched nature, happy animals, and healthy people" (Felt, 2015: 115). These imaginaries help perpetuate a vision of what makes Austria unique: it seems 'natural' to keep green biotechnology out, not least by promoting domestic organic food production. These cultural values tied to environmental protection are also expressed in the names of the two major organic brands: 'Ja!Natürlich' (Yes!Naturally) and 'Natur Pur' (Pure Nature), names that reinforce the link between organic food and pristine nature.

In Italy consumers reacted strongly in the face of food scares, which were portrayed as coming from 'outside', as being 'foreign'. This allowed to position food produced domestically as safe and natural. However, this mobilization did not focus solely on organic food, but included various iconic regional foods, traditional specialities, and well-established geographical indications (Sassatelli and Scott, 2001; Brunori et al., 2013). At the same time, organic food benefits from high trust levels, not least due to the proven ability of the Italian certification system to discover frauds (Gambelli et al., 2014). In particular, 'organic' is seen as a strong identifier for environmentally related quality (Zanoli et al., 2012). Organic food is thus widely available both through conventional supermarkets (e.g. COOP, the largest Italian food retailer having an own private label), and through specialised shops and retailer chains (e.g. EcorNaturaSi). Next to a growing domestic demand, the organic sector in Italy is strongly shaped by the relations it built with exporters. Indeed, over a third of Italian organic production is exported (Defrancesco and Rosseto, 2007). The exported products are mostly fruits and vegetables, olive oil, wine, citrus fruits, and pasta. This exportorientated production is driven by the strong demand for organic products from Southern Italy. Indeed, these cannot be produced in northern Europe, where the demand for organic products is high, and where Italian organic products enjoy a good reputation (Marchesini and Zanetti, 1995, 1997; Zanoli et al., 1999; Callieris et al., 2010).

In France, consumers are similarly committed to traditional specialities and geographical indications as in Italy (Barham and Sylvander, 2011). Organic foods thus need to position themselves against these wellestablished quality labels. This particularly applies to mainstream supermarkets, which have entered the organic market rather late. Organic foods are widely available through specialized organic retailers, such as Biocoop, which has been engaged in the organic sector since 1986 and is one of the largest organic supermarket chain in Europe. Biocoop promotes not only the naturalness of organic products, but also advocates for fairness in the food value chain (Dufeu and Le Velly, 2016; Lamine and Noe, 2017). Due to an increasing demand for organic products, selling organic food has become a profitable business and specialised organic shops are mushrooming, particularly in urban areas and mainstream supermarkets are constantly enlarging their offer in organic products.

The relations between the organic sector and various actors of the conventional value chains, especially supermarkets and exporters, are quite different in the three countries. The different relations between the organic sector and consumers through supermarkets is indicated by the share of organic retail shares, as in Austria supermarkets account for $78 \%$ of organic retail sales, compared to $40 \%$ in Italy, and $45 \%$ in France (IFOAM EU, 2016). But consumers do not only have different relations with organic food based on marketing channels, there are also differences in per capita spending for organic food, with $127 € /$ capita/year in Austria, compared to $73.40 €$ in France, and $35.30 €$ in Italy (IFOAM EU, 2016). This may point to differences in the extent to which organic food has to compete with established quality food labels, such as geographical indications and traditional specialities in Italy and in France. 
Agriculture in Austria, Italy, and France faced similar agricultural modernisation policies in the 1950s and 1960s, which resulted in comparable social and environmental impacts. In all three countries, organic farming was seen by some as a way to address the negative side of these impacts, leading to the emergence of an organic sector. Yet, over a 25-year period the dynamics of the organic sectors were quite different. The relational perspective highlights that the dynamics of the organic sector in each country is less attributable to one or a few causes, but rather the emergent result of situated networks of relations.

For example, the level and the continuity of direct payments offered to organic farmers in Austria doubtlessly contributed to the steady growth of its organic area (Fig. 1). However, from a relational perspective, the payments were only successful because of the many other relations that were successfully tied to organic farming, such as it being a way to maintain traditional farming and thus the cultural landscape in the Alps which is valued by Austrians as well as by tourists; organic food being tied to 'consumer patriotism' in the context of EU accession; and that only organic food could guarantee that it was 'GMO-free'. Thus it would be misleading to reduce the development of organic farming in Austria to one specific cause, such as the direct payments to farmers. It may be more helpful to understand these payments as a visible indicator of a much more wider network of meaningful relations. A relational perspective thus highlights the importance of the context. This concerns the temporal context, i.e. the specific issues that were salient in agriculture in the mid-1990s in Austria, such as the cost of export subsidies due to over-production and consumers' perceptions in the wake of EU-accession. But it also concerns the spatial context, i.e. the specific situation in Austria, such as the cultural values tied to agriculture and the lack of alternative food label to convey 'Austrianness'. It thus remains an empirical question whether similarly designed payments would have had the same effect in they would have been offered in Austria a decade later, or if they were offered in another country.

A relational perspective thus highlights not just that the effectiveness of an action is dependent on many other relations, but also that this causal pattern is tied to a specific time and place. Indeed, expectations, preferences, perceptions, and meanings of a set of practices will differ, depending on the context. This context will influence what shared meanings can be constructed, what relations can be built. At the same time, the meanings that are successfully established feedback and change this context. Depending on the spatial and temporal context, organic agriculture and organic food may or may not be successfully mobilized to address concerns such as the maintenance of family farms, environmental protection, animal welfare, climate change, food miles, or fairness in the food chain. And if organic farming is successfully mobilized, it impacts the dominant discourse regarding desirable agricultural practices and qualities in food.

The differences in understandings of - and imaginaries tied to - agriculture in Austria, Italy, and France have enabled different relations to be tied to organic practices. In Austria agriculture is understood as multifunctional, and thus as (also) providing a public good. This enabled organic farming associations to highlight their contribution to maintaining family farms and the cultural landscape. In contrast, in France, agriculture has been looked at primarily through its productive function and through a technicist-modernist frame, which made it more difficult for organic actors to build relations with the State and other societal actors. Similarly, while in Austria organic food was associated with 'local' and became the prime label for 'quality' in food; in Italy and in France consumers had well-established associations with traditional specialities and geographical indications, and 'local' was not tied to 'organic' in the same way as in Austria, so that it was more difficult for organic food to convey a relevant 'quality'.

The dynamics of the organic sectors in Austria, Italy, and France also show that there was no determinism in their development. The events did not unfold along an inevitable path, where the impact of an individual action or event could have been predicted. Indeed, the dynamics of the organic sector are not tied to an intrinsic quality of organic farming. Rather, the dynamics are tied to the relations that were built, maintained, changed, severed, reshaped by various organic actors. The relations that were successfully established depended on the initiative of various actors, on the opportunities afforded by the national context, and on the competing efforts by actors tied to conventional agriculture or other alternatives, such 
as agroecology. The dynamics thus emerged from a host of economic, material, technological, cultural, moral, and emotional relations tied with a variety of actors in the agrifood system. These relations are always under construction, are always being made, always unfinished, with actors involved in an ongoing process of building, strengthening, maintaining, weakeing and breaking relations, in their response to new possibilities and to unfolding meanings (Chia, 1999; Kjeldsen and Ingemann, 2009; Balducci et al., 2011; Allen, 2012; Lehtimäki, 2018). Thus, from a relational perspective, the organic sector is always changing and changing in different ways in each countries.

Depending on their history, actors may perceive more or fewer options, influenced by past conflicts as well as by collaborative relations that were successfully established. Indeed, past experiences influence present actors and present opportunities, as they influence the processual memories and thus the relations actors see as possible and promising (Dépelteau, 2018b). As a result, emerging opportunities are perceived and enacted differently in different countries. Organic actors may or may not be in a position to build relations that enable them to take advantage of events, such as the anti-GMO-stance in Austria, the BSE-crisis in Italy, or the farm-level cost-price crisis in France. Such events are not understood as a trigger in and of themselves, but as meaningful for the organic sector only if they are perceived as a 'window of opportunity' (Brédart and Stassart, 2017).

The dynamics of the organic sector show both the limits of events to promote more sustainable agricultural and food practices, but also the opportunities they may offer. Indeed, such events should not be treated as anomalies, ignored for the benefit of regularities (see Dépelteau 2018b). The events may well be intimately tied to the complexities of a globalized world, and thus a standard feature of life in fluid modernity (Bauman, 2007). The question is then not whether such events will affect the dynamics of agrifood systems, but whether actors are able to use them to strengthen relations and build novel ones; and if yes, which actors? With whom? Based on what argument? By focusing on how such relations are built and broken, relational sociology might afford new insights into the dynamics of the organic sector as well as the wider agrifood sector, highlighting the role of tumultuous processes of confusion, disjoint, disorganization, rupture, and (failed) re-organization (see Dépelteau 2018b).

Through this type of analysis, a relational perspective may be able to identify some relevant temporary social patterns; yet the goal is not to predict future interactions. Indeed, a relational perspective shows that while the dynamics of an organic sector might be reconstructed in hindsight, a transformation of agrifood systems towards sustainability will be unpredictable in how it progresses, why it progresses, and what specific expression it takes in each place. A relational perspective points towards the futility of the search for universal social 'laws', i.e. 'social forces' that will have the same effect, independent of time and space, of history and context. It may not be helpful to search for the one (or a few) variables that explain a specific dynamic. It may be unduly limiting to focus on identifying similarities in patterns and identifying mechanism that may allow to reproduce these patterns. It may be more helpful to acknowledge that the social universe is "complex, dynamic and quite messy" (Dépelteau, 2018b:503).

A relational perspective understands the agrifood system as vibrant, undergoing constant change, driven by multiple social processes. Enabling the spread of sustainable agrifood systems will be influenced by what various actors perceive as desirable at a particular time and place, by the ability of actors to build and maintain relations based on alternate narratives of how current problems can be effectively addressed. But it will also be heavily influenced by the actors' flexibility when engaging in fluid social processes, their ability to recognize and use windows of opportunity, to explore new ways to make sense of a situation, to reframe and reinterpret the meaning of a sustainable production practice to address a salient issue. By emphasising dynamics and change, rather than stability and constraints, a relational perspective thus highlights the role of creativity in actions. It joins the 'politics of possibility' (Gibson-Graham, 2006) in pointing out that there are no blueprints, that change is contingent and place-based, that agriculture is not a field of invariant logics and automatic unfoldings.

\section{Acknowledgements}


The authors would like to thank the anonymous reviewers for their insightful comments which were instrumental in improving the manuscript. We also extend our thanks to Michael Eder, Claire Lamine, Allison Loconto, and Anton Pinshoff for their incisive comments on previous versions of this article. Of course, the responsibility for our interpretation of relations and dynamics remains ours alone.

\section{References}

Agence Bio, 2017. L'agriculture Bio séduit de plus en plus de consommateurs et doit relever le défi de la croissance. Dossier de Presse. http://www.agencebio.org/sites/default/files/upload/dp agencebio 150917 val.pdf

Allen, J., 2012. A more than relational geography? Dialogues in Human Geography 2, 190e193. doi:10.1177/2043820612449295

Allen, P., Kovach, M., 2000. The capitalist composition of organic: The potential of markets in fulfilling the promise of organic agriculture. Agriculture and Human Values 17, 221-232. doi:10.1023/a:1007640506965

Alrøe, H., Noe, E., 2008. What makes organic agriculture move: protest, meaning or market? A polyocular approach to the dynamics and governance of organic agriculture. International Journal of Agricultural Resources, Governance and Ecology 7, 5-22. doi:10.1504/IJARGE.2008.016976

Andersen, A.H., 2011. Organic food and the plural moralities of food provisioning. Journal of Rural Studies 27, 440-450. doi: 10.1016/j.jrurstud.2011.07.004

Ansaloni, M., 2015. Le tournant environnemental de la PAC. Débats et coalitions en France, en Hongrie et au Royaume-Uni. L'Harmattan, Paris.

Ansaloni, M., Fouilleux, E., 2008. Terroir et protection de l'environnement: Un marriage indésirable? A propos d'intégration de critères environnementaux dans un instrument de politique agricole. Politiques et Management Public 26, 3-24. doi:10.4000/pmp.1569

Balducci, A., Boelens, L., Hillier, J., Nyseth, T., Wilkinson, C., 2011. Strategic spatial planning in uncertainty: theory and explanatory practice. Town Planning Review 82, 481e501. doi:10.3828/tpr.2011.29

Barham, E., Sylvander, B., 2011. Labels of origin for food: Local development, global recognition. CABI Publishing, Wallingford.

Bartoli, L., De Rosa, M., 2010. Consuming policy in a coherent way: some differences in the Italian agrifood districts. Paper presented at the $9^{\text {th }}$ European IFSA Symposium held 4-7 July 2010 in Vienna.

Bauman, Z., 2007. Liquid times. Living in an age of uncertainty. Polity Press, Cambridge.

Bellon, S., Gautronneau, Y., Riba, G., Savini, I., Sylvander, B., Hervieu, B. 2000. L'agriculture biologique et I'INRA: vers un programme de recherche. INRA mensuel 104, 1-25.

Bellon, S., Penvern, S. (eds), 2014. Organic farming, prototype for sustainable agricultures. Springer, Dordrecht.

Best, H. 2008. Organic agriculture and the conventionalization hypothesis: a case study from West Germany. Agriculture and Human Values 25, 95-106. doi:10.1007/s10460-007-9073-1

Bivar, V., 2018. Organic resistance: The struggle over industrial farming in postwar France. University of North Carolina Press, Chapel Hill.

Bouttes, M., Darnhofer, I., Martin, G., 2018. Converting to organic farming as a way to enhance adaptive capacity. Organic Agriculture, in press. doi:10.1007/s13165-018-0225-y 
Brédart, D., Stassart, P., 2017. When farmers learn through dialog with their practices: A proposal for a theory of action for agricultural trajectories. Journal of Rural Studies 53, 1-13. doi:10.1016/i.jrurstud.2017.04.009

Brunori, G., Malandrin, V., Rossi, A., 2013. Trade-off or convergence? The role of food security in the evolution of food discourse in Italy. Journal of Rural Studies 29, 19-29. doi:10.1016/j.jrurstud.2012.01.013

Brzezina, N., Biely, K., Helfgott, A., Kopainsky, B., Vervoort, J., Mathijs, E., 2017. Development of organic farming in europe at the crossroads: Looking for the way forward through system archetypes lenses. Sustainability 9, 5. doi:10.3390/su9050821

Callieris, R., Cardone, G., Guarrera, L., Pinton, R., Santucci, F., 2010. Produzioni biologiche italiane: dinamiche interne e prospettive commerciali sui mercati esteri. InterBio and CIHEAM, Bari. weblink

Campbell, C., Liepins, R., 2001. Naming organics: understanding organic standards in New Zealand as a discursive field. Sociologia Ruralis 41, 21-39. doi:10.1111/1467-9523.00168

Chia, R., 1999. A 'rhizomic' model of organizational change and transformation: Perspective from a metaphysics of change. British Journal of Management 10, 209-227. doi:10.1111/1467-8551.00128

Compagnoni, A., Pinton, R., Zanoli, R., 2000. Organic farming in Italy. In: Graf, S., Willer, H. (Eds). Organic Agriculture in Europe. Stiftung Ökologie \& Landbau, Bad Dürkheim, pp. 171-183. Weblink

Dabbert, S., Haering, A. M., Zanoli, R., 2004. Organic Farming. Policies and Prospects. Zed Books, London.

Darnhofer, I., Lindenthal, T., Bartel-Kratochvil, R., Zollitsch, W., 2010. Conventionalisation of organic farming practices: from structural criteria towards an assessment based on organic principles. A review. Agronomy for Sustainable Development 30, 67-81. doi:10.1051/agro/2009011

De Cock, L., Dessein, J., de Krom, M., 2016. Understanding the development of organic agriculture in Flanders (Belgium): A discourse analytical approach. NJAS - Wageningen Journal of Life Sciences 79, 1-10. doi:10.1016/j.njas.2016.04.002

de Silguy, C., 2015. L'APCA et l'agriculture biologique, une conversion à petits pas. Pour 227, 97-100. doi:10.3917/pour.227.0097

Defrancesco, E., Rosseto, L., 2007. From niche to market: the growth of organic business in Italy. In: Canavari, M., Olson, K. (eds). Organic food. Consumers' choices and farmers' opportunities. Springer, New York, pp. 3-16.

Dépelteau, F., 2013. What is the direction of the 'relational turn'? In: C. Powell and F. Dépelteau (eds). Conceptualizing relational sociology. Palgrave Macmillan, New York, pp. 163-187. doi:10.1057/9781137342652 10

Desquilbet, M., Maigné, E., Monnier-Dihan, S., 2017. Organic food retailing and the conventionalization debate. Working Paper 17-778, Toulouse School of Economics, Toulouse. weblink

Dufeu, I., Le Velly, R., 2016. Quelle régulation pour les filières biologiques? Innovations Agronomiques 51, 67-76. doi:10.15454/1.4721178116757644E12

Eacott, S., 2018. Beyond Leadership: A relational approach to organizational theory in education. Springer Nature, Singapore. doi:10.1007/978-981-10-6568-2

EC, 2016. Facts and figures on organic agriculture in the European Union. DG Agriculture and Rural Development. European Commission, Brussels. Available from: http://ec.europa.eu/agriculture/rica/pdf/Organic 2016 web new.pdf

Eden, S., 2011. Food labels as boundary objects: How consumers make sense of organic and functional foods. Public Understanding of Science 20, 179-194. doi:10.1177/0963662509336714

Emirbayer, M., 1997. Manifesto for a relational sociology. American Journal of Sociology 103, 281-317. doi:10.1086/231209 
Felt, U., 2015. Keeping technologies out: sociotechnical imaginaries and the formation of Austria's technopolitical identity. In: S. Jasanoff, S.-H. Kim (eds). Dreamscapes of modernity. Sociotechnical imaginaries and the fabrication of power. University of Chicago Press, Chicago, pp. 103-125.

Filippini, R., De Noni, I., Corsi, S., Spigarolo, R., Bocchi, S., 2018. Sustainable school food procurement: What factors do affect the introduction and the increase of organic food? Food Policy 76, 109-119. doi:10.1016/j.foodpol.2018.03.011

Fouilleux, E., 2003. La PAC et ses réformes. Une politique à l'épreuve de la globalisation. L'Harmattan, Paris.

Fouilleux, E., Loconto, A., 2017a. Voluntary standards, certification, and accreditation in the global organic agriculture field: a tripartite model of techno-politics. Agriculture and Human Values 34, 1-14. doi:10.1007/s10460-016-9686-3

Fouilleux E., Loconto A., 2017b. En coulisse des labels: régulation tripartite et marchés imbriqués. De l'européanisation à la globalisation de l'agriculture biologique. Revue Française de Sociologie 58, 501-531. doi:10.3917/rfs.583.0501

Freyer, B., Bingen, J. (eds.), 2014. Re-thinking organic food and farming in a changing world. Springer, Dordrecht.

Gambelli, D., Solfanelli, F., Zanoli, R., Zorn, A., Lippert, C., Dabbert, S., 2014. Non-compliance in organic farming: A cross-country comparison of Italy and Germany. Food Policy 49, part 2, 425-428. doi:10.1016/j.foodpol.2014.05.009

Gangneron, E., 2015. La vision de l'agriculture bio à l'APCA. Pour 227, 101-108. doi:10.3917/pour.227.0101

Gibbon, P., 2008. An analysis of standards-based regulation in the EU organic sector, 1991-2007. Journal of Agrarian Change 8, 553-582. doi:10.1111/i.1471-0366.2008.00180.x

Gibson-Graham, J.K., 2006. A postcapitalist politics. University of Minnesota Press, Minneapolis.

Green, K., Foster, C., 2005. Give peas a chance. Transformations in food consumption and production systems. Technological Forecasting and Social Change 72, 663-679. doi:10.1016/j.techfore.2004.12.005

Grin, J., 2012. The politics of transition governance in Dutch agriculture. Conceptual understanding and implications for transition management. Int. J. Sustainable Development 15, 72-89. doi:10.1504/IJSD.2012.044035

Groier, M., 2005. Entwicklung, Struktur und Förderung des biologischen Landbaus. In: Groier, M., Gleirscher, N. (eds). Bio-Landbau in Österreich im internationalen Kontext. Band 1: Strukturentwicklung, Förderung, Markt. Forschungsbericht 54. BABF, Vienna.

Guthman, J. 2004. Agrarian dreams: The paradox of organic farming in California. University of California Press, Oakland.

Guyomard, H. (ed), 2013. Vers des agricultures à haute performances. Volume 1: Analyse des performances de l'agriculture biologique. INRA, Paris. weblink

Home, R., Bouagnimbeck, H., Ugas, R., Arbenz, M. Stolze, M., 2017. Participatory guarantee systems: organic certification to empower farmers and strengthen communities. Agroecology and Sustainable Food Systems 41, 526-545. doi:10.1080/21683565.2017.1279702

IFOAM EU, 2016. Organic in Europe. Prospects and developments 2016. IFOAM EU Group, Brussels. weblink

Ilbery, B., Maye, D., 2005. Alternative (shorter) food supply chains and specialist livestock products in the Scottish-English borders. Environment and Planning A: Economy and Space 35, 823-844. doi:10.1068/a3717

Jobert, B., Muller, P., 1987. L'état en action. Presses Universitaires de France, Paris.

Jordan, G., Maloney, W., and A. M. McLaughlin, A., 1994. Characterizing agricultural policy-making. Public 
Administration 72, 505-526. doi:10.1111/j.1467-9299.1994.tb00806.x

Jurtschitsch, A., 2010. Bio-Pioniere in Österreich. Böhlau, Vienna.

Kaltoft, P., 1999. Values about nature in organic farming practice and knowledge. Sociologia Ruralis 39, 3953. doi:10.1111/1467-9523.00092

Kaltoft, P., 2001. Organic farming in late modernity: At the frontier of modernity or opposing modernity? Sociologia Ruralis 41, 146-158. doi:10.1111/1467-9523.00174

Kaufmann, P., Stagl, S., Franks, D.W., 2009. Stimulating the diffusion of organic farming practices in two new EU Member States. Ecological Economics 68, 2580-2593. doi:10.1016/j.ecolecon.2009.04.001

Kerselaers, E., De Cock, L., Lauwers, L., Van Huylenbroeck, G., 2007. Modelling farm-level economic potential for conversion to organic farming. Agricultural Systems 94, 671-682. doi:10.1016/i.agsy.2007.02.007

King, A., 2000. Thinking with Bourdieu against Bourdieu: A 'practical' critique of the Habitus. Sociological Theory 18, 417-433. doi:10.1111/0735-2751.00109

Kjeldsen, C., Ingemann, J., 2009. From the social to the economic and beyond? A relational approach to the organic food networks. Sociologia Ruralis 49, 151-171. doi:10.1111/j.1467-9523.2009.00487.x

Klein, K., Winickoff, D., 2012. Organic regulation across the Atlantic: emergence, divergence, convergence. Environmental Politics 20, 37-41. doi:10.1080/09644016.2011.551022

Knowles, T., Moody, R., McEachern, M., 2007. European food scares and their impact on EU food policy. British Food Journal 109, 43-67. doi:10.1108/00070700710718507

Lamine, C., 2011. Transition pathways towards a robust ecologization of agriculture and the need for system redesign. Cases from organic farming and IPM. Journal of Rural Studies 27, 209-219. doi:10.1016/j.jrurstud.2011.02.001

Lamine, C., 2017. La fabrique sociale de l'écologisation de l'agriculture. Éditions la Discussion, Marseille.

Lamine C., Noe E., 2017. Values and volumes in sustainable organic market chains - A multiperspectival analysis. International Journal of Sociology of Agriculture and Food 24, 15-36. weblink

Lamine, C., Darolt, M., Brandenburg, A., 2012. The civic and social dimensions of food production and distribution in Alternative Food Networks in France and in Brazil. International Journal of Sociology of Agriculture and Food 19, 383-401. weblink

Lampkin, N., Foster, C., Padel, S., 1999. The policy and regulatory environment for organic farming in Europe: Country reports. Organic Farming in Europe: Economics and Policy, Volume 2. Hohenheim: University of Hohenheim.

Läpple, D., 2010. Adoption and abandonment of organic farming: an empirical investigation of the Irish drystock sector. Journal of Agricultural Economics 61, 697-714. doi:10.1111/j.14779552.2010.00260.x

Le Velly, R., 2017. Sociologie des systèmes alimentaires alternatifs. Une promesse de différence. Presses des Mines, Paris.

Lehtimäki, T., 2018. Constructing relations between organic and conventional agriculture in Finland in the emergence of organic agriculture. Sociologia Ruralis, in press. doi:10.1111/soru.12222

Leroux B., 2011. Les agriculteurs biologiques et l'alternative: contribution à une anthropologie politique d'un monde paysan en devenir. EHESS, Paris.

Leroux B., 2015. L'émergence de l'agriculture biologique en France: 1950-1990. POUR, 59-66. doi:10.3917/pour.227.0059

Lesjak, H., 2008. Explaining organic farming through past policies: comparing support policies of the EU, Austria and Finland. Journal of Cleaner Production 16, 1-11. doi:10.1016/j.jclepro.2006.06.005 
Lobley, M., Butler, A., Winter, M., 2013. Local organic food for local people? Organic marketing strategies in England and Wales. Regional Studies 47, 216-228. doi:10.1080/00343404.2010.546780

Lockeretz W., 2007. Organic farming: an international history. CABI, Wallingford.

Lynggaard, K., 2007. The institutional construction of a policy field: a discursive institutional perspective on change within the common agricultural policy. Journal of European Public Policy 14, 293-312. doi:10.1080/13501760601122670

Marchesini, L., Zanetti, F., 1995. Indagine sul controllo e la certificazione nel settore dell'agricoltura biologica: primi risultati in Santucci, F., M. and Zanoli, R. (Eds) Agricoltura biologica in Italia: aspetti tecnici, economici e normativi Convegno Nazionale, 22-23 febbraio 1995, Polo Universitario di Monte Dago

Marchesini, L., Zanetti, F., 1997. La doppia faccia dell'agricoltura biologica: un'indagine sul controllo e la certificazione. Rivista di Politica Agraria 15, 15-22.

Michelsen, J., 2001. Organic farming in a regulatory perspective. The Danish case. Sociologia Ruralis 41, 6284. doi:10.1111/1467-9523.00170

Michelsen, J., 2009. The Europeanization of organic agriculture and conflicts over agricultural policy. Food Policy 34, 252-257. doi:10.1016/j.foodpol.2009.03.004

Morgan, K., Murdoch, J., 2000. Organic vs. conventional agriculture: knowledge, power and innovation in the food chain. Geoforum 31, 159-173. doi:10.1016/S0016-7185(99)00029-9

Morgan, K., Sonnino, R., 2008. The school food revolution: public food and the challenge of sustainable development. Earthscan, London.

Moschitz, H., 2009. Moving on - European organic farming movements between political action and selfreflection. Int. Journal of Agricultural Resources, Governance, and Ecology 8, 371-387. doi:10.1504/IJARGE.2009.032641

Muller, P., 2000. La politique agricole française: l'État et les organisations professionnelles. Économie Rurale 255-256, 33-39. doi:10.3406/ecoru.2000.5153

Murdoch, J., Miele, M., 1999. 'Back to nature': changing 'worlds of production' in the food sector. Sociologia Ruralis 39, 465-483. doi:10.1111/1467-9523.00119

Naspetti, S., Zanoli, R., 2014. Organic consumption as a change of mind? Exploring consumer narratives using a structural cognitive approach. Journal of International Food and Agribusiness Marketing 26, 258-285. doi:10.1080/08974438.2013.833566

Nicholas, P., Jeffeys, I., Lampkin, N., 2006. Effects of European organic farming policies at sectoral and societal levels. Aspects of Applied Biology 79, 163-166.

Nieberg, H., Kuhnert, H., 2006. Förderung Des Ökologischen Landbaus in Deutschland: Stand, Entwicklung und Internationale Perspektive. Landbauforschung Völkenrode, Sonderheft 295. Bundesforschungsanstalt für Landwirtschaft, Braunschweig.

Offermann, F., Nieberg, H., Zander, K., 2009. Dependency of organic farms on direct payments in selected EU member states: today and tomorrow. Food Policy 34, 273-279. doi:10.1016/j.foodpol.2009.03.002

Ortmayr, N., 2007. Überschusskrisen in der europäischen Landwirtschaft. Österreich 1970-1994 als Fallbeispiel. Zeitgeschichte 34, 162-178.

Padel, S., Lampin, N., Foster, C. 1999. Influence of policy support on the development of organic farming in the EU. International Planning Studies 4, 303-315. doi:10.1080/13563479908721744

Padel, S., Midmore, P., 2005. The development of the European market for organic products: Insights from a Delphi study. British Food Journal 107, 626-646. doi:10.1108/00070700510611011 
Padel, S., Röcklinsberg, H., Schmid, O., 2009. The implementation of organic principles and values in the European Regulation for organic food. Food Policy 34, 245-251. doi:10.1016/j.foodpol.2009.03.008

Pahun, J., 2018. 'Manger local': canalisation politique des débats sur l'alimentation en région. In: Fouilleux E., Michel, L. (eds). Gouverner l'Alimentation. Presses de Science Po, Paris.

Paltrinieri, R. and Spillare, S., 2015. L'Italia del biologico. Un fenomeno sociale, dal campo alla città. Edizioni Ambiente, Milano.

Pirklhuber, W., Gründlinger, K., 1993. Der biologische Landbau in Österreich. Ein Beitrag zur umweltverträglichen Landbewirtschaftung. Monographien Band 35. Umweltbundesamt, Wien.

Poméon, T., Fouilleux, E., Lemeilleur, S., Laconto, A., 2017. L'agriculture biologique en France, entre projet critique et conventionnalisation. In: Allaire, G., Daviron B. (eds). Transformations agricoles et agroalimentaires. Entre écologie et capitalisme. Quae, Versailles, pp. 181-198.

Posch, A., 2013. Biologische Landwirtschaft - Erreicht der Biolandbau den Menschen? Meine Erfahrungen. Presentation at the Agricultural School Schlägl on 18 January 2013. Weblink

Powell, C., 2013. Radical relationism: a proposal. In: C. Powell and F. Dépelteau (eds). Conceptualizing relational sociology. Palgrave Macmillan, New York, pp. 87-104. doi:10.1057/9781137342652 6

Powell, C., Dépelteau, F., 2013. Introduction. In: C. Powell and F. Dépelteau (eds). Conceptualizing relational sociology. Palgrave Macmillan, New York, pp. 1-12. doi:10.1057/9781137342652 1

Pratt, J., 2009. Incorporation and resistance: Analytical issues in the conventionalization debate and alternative food chains. Journal of Agrarian Change 9, 155-174. doi:10.1111/i.14710366.2009.00190.x

Rahmann, G., Reza Ardakani, M., Bàrberi, P., Boehm, H., Canali, S., Chander, M., ... Zanoli, R., 2017. Organic agriculture 3.0 is innovation with research. Organic Agriculture 7, 3. doi:10.1007/s13165-016-0171-5

Rech, T., 2003. Organic food for public institutions. In: Organic agriculture. Sustainability, markets and policies. OECD, Paris, pp. 401-406.

Reed, M. 2001. Fight the future! How the contemporary campaigns of the UK organic movement have arisen from their composting of the past. Sociologia Ruralis 41, 131-145. doi:10.1111/14679523.00173

Rodet, D., 2014. Produire 'un peu' ou 'totalement' autrement? Hétérogénéité des utopies de l'économie solidaire en France. Lien social et Politiques 72, 209-228. doi:10.7202/1027214ar

Rodet, D., 2017. Construire un système agro-alimentaire alternatif: les cas des AMAP et de 'La Ruche qui dit oui!'. Presentation at the biannual conference of the Association Francaise de Science Politique (AFSP), held 12-13 July 2017 in Montpellier, France.

Rosin, C., Campbell, H., 2009. Beyond bifurcation: Examining the conventions of organic agriculture in New Zealand. Journal of Rural Studies 25, 35-47. doi:10.1016/j.jrurstud.2008.05.002

Sanders, J.; Stolze, M., Padel, S., 2011. Use and efficiency of public support measures addressing organic farming. Johann Heinrich von Thünen-Institut (vTI), Braunschweig.

Sassatelli, R., Scott, A., 2001. Novel food, new markets and trust regimes. Responses to the erosion of consumers' confidence in Austria, Italy and the UK. European Societies 3, 213-244. doi:10.1080/146166901200543339

Schermer, M., 2005. Die institutionelle Organisation des Biolandbaues in Österreich. In: Zwischen Professionaliserung und Konventionalisierung. Forschungsbericht 55. Bundesanstalt für Bergbauernfragen, Wien, pp. 5-15.

Schermer, M., 2008. Organic policy in Austria: greening and greenwashing. International Journal of Agricultural Resources, Governance and Ecology 7, 40-50. doi:10.1504/IJARGE.2008.016978 
Schermer, M., 2014. From 'food from nowhere' to 'food from here': changing producer-consumer relations in Austria. Agriculture and Human Values 32, 121-132. doi:10.1007/s10460-014-9529-z

Seifert, F., 2009. Consensual NIMBYs, contentious NIABYs: Explaining contrasting forms of farmers GMO opposition in Austria and France. Sociologia Ruralis 49, 20-40. doi:10.1111/j.14679523.2008.00473.x

Seufert, V., Ramankutty, N., Mayerhofer, T., 2017. What is this thing called organic? How organic farming is codified in regulations. Food Policy 68, 10-20. doi:10.1016/j.foodpol.2016.12.009

Stassart, P., Jamar, D., 2008. Steak up the horns! The conventionalization of organic stock farming: knowledge lock-in in the agrifood chain. GeoJournal 73, 31-44. doi:10.1007/s10708-008-9176-2

Stolze, M., Lampkin, N., 2009. Policy for organic farming: Rationale and concepts. Food Policy 34, 237-244. doi:10.1016/i.foodpol.2009.03.005

Thorsøe, M., Noe, E., 2015. Cultivating market relations - Diversification in the Danish organic production sector following market expansion. Sociologia Ruralis 56, 331-348. doi:10.1111/soru.12086

Tomlinson, I., 2008. Re-thinking the transformation of organics: the role of the UK government in shaping British organic food and farming. Sociologia Ruralis 48, 133-151. doi:10.1111/j.14679523.2008.00457.x

Torgersen, H., Seifert, F., 2000. Austria: precautionary blockage of agricultural biotechnology. Journal of Risk Research 3, 209-217. doi:10.1080/13669870050043071

Tregear, A., Arfini, F., Belletti, G., Marescotti, A., 2007. Regional foods and rural development: the role of product qualification. Journal of Rural Studies 23, 12-22. doi:10.1016/j.jrurstud.2006.09.010

Tsekeris, C., 2013. Norbert Elias on relations: Insights and perspectives. In: C. Powell and F. Dépelteau (eds). Conceptualizing relational sociology. Palgrave Macmillan, New York, pp. 87-104. doi:10.1057/9781137342652 6

Vogl, C., Kilcher, L., Schmidt, H., 2005. Are standards and regulations of organic farming moving away from small farmer's knowledge? Journal of Sustainable Agriculture 26, 5-26. doi:10.1300/J064v26n01 03

Vos, T., 2000. Visions of the middle landscape: Organic farming and the politics of nature. Agriculture and Human Values 17, 245-256. doi:10.1023/A:1007623832251

Weis, T., 2010. The accelerating biophysical contradictions of industrial capitalist agriculture. Journal of Agrarian Change 10, 315-341. doi:10.1111/j.1471-0366.2010.00273.x

Zander, K., Nieberg, H., Offermann, F., 2008. Financial relevance of organic farming payments for Western and Eastern European organic farms. Renewable Agriculture and Food Systems 23, 53-61. doi:10.1017/S1742170507002050

Zanoli, R. (ed.) 2007. Le politiche per l'agricoltura biologica in Italia. Casi di studio nazionali e regionali. Angeli, Milano.

Zanoli, R., Gambelli, D., Vairo, D., Lampkin, N., Foster, C., Padel, S., 1999. Italy. In: Lampkin, N., Foster, C., Padel, S. (eds) The policy and regulatory environment for organic farming in Europe: Country Reports. Organic farming in Europe: economics and policy, Vol. 2. University Hohenheim, Hohenheim, pp. 298-328. file online

Zanoli, R., Scarpa, R., Napolitano, F., Piasentier, E., Naspetti, S., Bruschi, V., 2012. Organic label as an identifier of environmentally related quality: A consumer choice experiment on beef in Italy. Renewable Agriculture and Food Systems 28, 1-10. doi:10.1017/S1742170512000026 